\title{
AN AUDIT OF THE PATIENTS TREATED IN PAEDIATRIC SURGERY DEPARTMENT OF AD-DIN WOMEN'S MEDICAL COLLEGE HOSPITAL, DHAKA
}

\author{
MUSRAT RAHMAN ${ }^{1}$, REZAUL ISLAM ${ }^{2}$, S M AALIM²
}

\begin{abstract}
Background: Surgery without audit is like playing without keeping the score. Medical/Surgical Audit is the evaluation of the quality and efficiency of the surgical services offered to the patients by a group of Medical Personnel in a Hospital. A surgical Audit of the patients of Department of Pediatric Surgery in a non-government Hospital was performed to evaluate overall performance and the quality of service delivered to the patients.
\end{abstract}

Methods: It was a randomized study carried out in the department of Pediatric surgery in Ad-din Women's' Medical College Hospital during the period of January 2008 to December 2012 (total 5 years). Total 4613 patients were included in this study. Among them $832(15.91 \%)$ patients were treated after admission and $4396(84.09 \%)$ patients were treated as OPD patients.

Results: Among the total $\mathbf{4 6 1 3}$ patients, 3953 patients were male and 660 patients were female. Total 3127 patients were under 5 years and 1486 patients were over 5 years. Among total 832 admission, $551(66.22 \%)$ were elective cases and 281 $(33.78 \%)$ were emergency cases.

Conclusion: Clinical audit is a process. It is a process used by clinicians who seek to improve patient care. So in this audit we have tried to evaluate our overall performance and the quality of service delivered to our patients in the last 5 years period to find out the limitations and deficiencies prevailing in this field.

Keywords: Audit, Paediatric Surgery Department, Ad-din Women's Medical College Hospital

\section{Introduction}

Surgery without audit is like playing without keeping the score. ${ }^{1}$ Clinical audit is a process. It is a process used by clinicians who seek to improve patient care.

1. Dr. Musrat Rahman, Department of Paediatric Surgery, Ad-din Women's Medical College Hospital (AWMCH), Dhaka

2. Dr. Rezaul Islam, S M AAlim, Department of Anaesthesiology, Ad-din Women's Medical College Hospital (AWMCH), Dhaka Correspondence to: Dr. Musrat Rahman, Associate Professor \& Head, Department of Paediatric Surgery, Ad-din Women's Medical College Hospital, Dhaka, Bangladesh, E-mail: musrat. deeba@gmail.com
The process involves comparing aspects of care (structure, process and outcome) against explicit criteria. A Medical/Surgical Audit is the evaluation of the quality and efficiency of the surgical services offered to the Patients by a group of Medical Personnel in a Hospital. When done by the persons concerned of the same Hospital/Unit it is called an internal audit, on the other hand an external audit is periodically done by an outside agency to verify the accuracy of internal audit. In such an audit hospital records of the concerned unit of a particular period are reviewed, analyzed and evaluated on the basis of different indicators to have an access to the quality of the patient's care, cost effectiveness and efficiency with which the care is provided. The aim is to safeguard the Patient's interest and find out the deficiencies in the field of hospital administration and professional skills. Ultimate objectives are to achieve highest standard of patients care \& services ${ }^{2}$.

Ad-din Women's Medical College Hospital is a 500 bedded General Hospital. Fifty beds in General Ward \& some Cabin facilities are allocated for Surgical Patients. Pediatric Surgery Department is functioning since 2000 and enjoys the facilities sharing within greater surgical activities. A Surgical Audit of the overall activities in this department was performed.

\section{Materials and Methods}

This is a retrospective internal audit conducted among the patients attended in SOPD, admitted and treated in the Pediatric Surgery Department of Ad-din Women's Medical College Hospital between January 2008 and December 2012. The infrastructure and manpower were meager in comparison to the workload (Table 1). The analysis and evaluation of the work were done on the basis of standard indicators used in surgical audit. 
The objectives of the audit were:

a) To evaluate overall performance,

b) To evaluate the quality of service delivered,

c) To find out the limitations and deficiencies prevailing in this field

\section{Table-I}

The facilities available in the Department of Pediatric Surgery

\begin{tabular}{|c|c|c|}
\hline $\begin{array}{l}\text { SL. } \\
\text { No. }\end{array}$ & Facilities & Number \\
\hline 1. & Number of beds & $10 \pm 5$ \\
\hline 2. & Consultant Surgeon & 1 \\
\hline 3. & House officers ( Doctors) & $3 \pm 2$ \\
\hline 4. & Nursing Staffs & 4 (On rotation duty) \\
\hline 5. & MLSS & 1 \\
\hline \multirow[t]{2}{*}{6.} & Admission : a. Emergency & Everyday \\
\hline & b. SOPD & Everyday \\
\hline \multirow[t]{2}{*}{7.} & Theatre facility : a. Emergency & $\begin{array}{l}\text { Every day, in share } \\
\text { with other SU }\end{array}$ \\
\hline & b. Schedule & $\begin{array}{l}\text { Twice weekly, another } \\
\text { days- in share }\end{array}$ \\
\hline
\end{tabular}

\section{Analysis of the Results:}

Over $85 \%$ patients were boys and $2-5$ year age group predominated followed by 01 year constituting about $67 \%$ below 5 years of age (Table 2). Minor surgical procedures formed the bulk of workload with circumcision accounting for $65 \%$ of total (Table $3 a$ ). Table $3 b$ depicts the different causes of intestinal obstruction. Analysis of works and outcomes are shown in table $4 \& 5$. The complications rates are somewhat low considering the small number of major operations (Table 6).

Table-II

Distribution of Age and Sex $(n=4613)$

\begin{tabular}{lccc}
\hline Age group & Male & Female & Total \\
\hline 0-1 year & 1018 & 348 & 1366 \\
2-5 years & 1581 & 180 & 1761 \\
6-9 years & 1201 & 87 & 1288 \\
10-12 years & 153 & 45 & 198 \\
\hline Total & 3953 & 660 & 4613 \\
\hline
\end{tabular}

Table 3a

Disease profile of Pediatric Surgical Patients $(n=4613)$

\begin{tabular}{|c|c|c|c|}
\hline SL. No. & Name of the Diseases & No. of Patients & Percentage(\%) \\
\hline 1. & Congenital Hernia/ Hydrocele (Inguinoscrotal) & 314 & 6.81 \\
\hline 2. & Abscess (Parietal, Perianal, Gluteal, Inguinal, Thigh, Neck, Axilla etc.) & 224 & 4.85 \\
\hline 3. & Rectal Polyp & 164 & 3.55 \\
\hline 4. & Umbilical granuloma & 131 & 2.84 \\
\hline 5. & Acute \& Recurrent Appendicitis/Burst Appendix & 96 & 2.08 \\
\hline 6. & Labial Adhesions & 88 & 1.91 \\
\hline 7. & Intestinal Obstruction & 78 & 1.69 \\
\hline 8. & Hypospadias & 70 & 1.52 \\
\hline 9. & Undescended testis & 52 & 1.13 \\
\hline 10. & Burn & 50 & 1.08 \\
\hline 11. & Tongue Tie & 44 & 0.95 \\
\hline 12. & Polydactyle/Syndactyle & 34 & 0.73 \\
\hline 13. & Congenital Cyst : Dermoid Cyst, Thyroglossal Cyst, Sacrococcygeal Teratoma & 16 & 0.35 \\
\hline 14. & Infantile Hypertrophic Pyloric stenosis & 14 & 0.30 \\
\hline 15. & Umbillical/Para Umbillical/Epigastric Hernia & 14 & 0.30 \\
\hline 16. & Cleft Lip/Cleft Palate & 12 & 0.26 \\
\hline 17. & Mucosal Cyst & 11 & 0.24 \\
\hline 18 & Hamartomas & 11 & 0.24 \\
\hline 19. & Torsion Testis & 9 & 0.19 \\
\hline 20. & Abdominal Lump-Ovarian Cyst, Mesenteric Cyst, Dermoid Cyst, Choledocal Cyst & 5 & 0.11 \\
\hline 21. & Perianal Sinus/Fistula & 5 & 0.11 \\
\hline 22. & Preauricular Sinus/Branchial Sinus & 4 & 0.09 \\
\hline 23. & Penile Torsion & 2 & 0.04 \\
\hline 24. & Patent Urachus & 1 & 0.02 \\
\hline 25. & Pilonidal Sinus & 1 & 0.02 \\
\hline 26. & Accessory Auricle & 1 & 0.02 \\
\hline 27. & $\begin{array}{l}\text { Minor Problems: Foreign body, Lipoma, Sebaceous Cyst, } \\
\text { Haematoma, Ganglion, FB Granuloma, Cut wound, Meatal Stenosis }\end{array}$ & 142 & 3.08 \\
\hline 28. & $\begin{array}{l}\text { Circumcision- Elective \& For some diseases- Phimosis, Balanoposthitis, } \\
\text { Recurrent U.T.I., Smegmal Cyst etc. }\end{array}$ & 3016 & 65.38 \\
\hline
\end{tabular}


Table 3b

Causes of Intestinal Obstruction in Children (78)

\begin{tabular}{llcc}
\hline SL. No. & Causes & Number & Percentage (\%) \\
\hline 1. & Anorectal Malformation & 24 & 30.77 \\
2. & Intussusception & 24 & 30.77 \\
3. & Neonatal Intestinal Obstruction- & 17 & 21.79 \\
& Intestinal Atresia & & \\
& Meconium lleus & 12 & 15.38 \\
4. & Hirschsprung's Disease & 1 & 1.28 \\
5. & Colonic Atresia & & \\
\hline
\end{tabular}

Table-IV

The analysis of the work done $(n=4613)$ :

\begin{tabular}{lllcc}
\hline SL. No. & Indicators & Types & No. & Percentage(\%) \\
\hline 1. & No of OPD visit & Everyday & All working days & 100 \\
2. & No of OPD patients & a) Admission & 832 & 15.91 \\
& $(5228)$ & b) Treatment as & 4396 & 84.09 \\
& & OPD pt. & & \\
3. & Admission (832) & a) Schedule & 551 & 66.22 \\
& & b) Emergency & 281 & 33.78 \\
4. & Operation performed & a) Elective & 4192 & 90.87 \\
& & b) Emergency & 421 & 9.13 \\
& & c) Major & 708 & 15.35 \\
5. & Anesthesia & d) Minor & 3905 & 84.65 \\
& & b) Leneral & 4250 & 92.13 \\
6. & Duration of Hospital Stay & Average three to seven days & 7.87 \\
7. & Cost involvement(Approx) & Totally personal & Tk.=3,000 to per patient & 15,000 \\
\hline
\end{tabular}

Table-V

Outcome of the Patients ( $n=4613)$

\begin{tabular}{llcc}
\hline SL.No. & Indicators & Number & Percentage \\
\hline 1. & Uneventful recovery & 4599 & 99.70 \\
2. & Complications- & 11 & 0.24 \\
& a) Peroperative & 2 & 0.04 \\
& b) Post operative: Major & & \\
Minor & 63 & 0.130 .06 \\
3. & Death- & 0 & 0.06 \\
& a) Per operative & 0.00 \\
& b)Post operative- & 3 & 0.06 \\
& Net death (>24hrs.) & & \\
& Septcaemia due to late \\
& Presentation \& poor general & \\
& condition. \\
\hline
\end{tabular}

Table-VI

Complications $(n=11)$

\begin{tabular}{llcc}
\hline SL.No. & Complications & Number & Percentage \\
\hline 1. & Peroperative- & & \\
& $\begin{array}{l}\text { Cardiac Arrest } \\
\text { 2. }\end{array}$ & 2 & 0.04 \\
& $\begin{array}{l}\text { Post operative- } \\
\text { Major- Post } \\
\text { Urethroplasty }\end{array}$ & 6 & 0.13 \\
& $\begin{array}{l}\text { Fistula } \\
\text { Minor- Wound } \\
\text { infection }\end{array}$ & 3 & 0.06 \\
\hline
\end{tabular}




\section{Discussion}

The predominance of male may be explicable by the fact that circumcision was done in over $65 \%$ patients and also by preferential treatment to the boys than the girls in our society ${ }^{3}$.

Tables IIla \&b are showing the picture of mostly general pediatric surgical conditions which is consistent with that found in standard textbook of Pediatric Surgeryt . In my study circumcision, inguinal hernia \& hydrocele are the commonest problems which are also mentioned in most text booksu. The result also shows that routine admissions (66.22) \& operations were almost twice than emergency admissions $(33.78 \%)$ \& operations. This may be due to lack of full-fledged round the clock emergency services. Out of $4250(92.13 \%)$ general anesthesia, only 2 cases developed per-operative cardiac arrest. About $99.70 \%$ of the children recovered smoothly. This is due to enriched Anesthesiology department with special expertness in pediatric anesthesia. Out of 4613 patients only 3patient $(0.06 \%)$ died, all of them due to very late presentation with critically ill neonatal cases (Table-V).

This audit has enabled us to identify many limitations and deficiencies prevailing in this field of hospital services. Those are lack of proper planning and organization, lack of coordination and accountability in hospital administrationv. Lack of full time emergency service with trained doctors is the main cause of decreased emergency admission and operation.

The essential prerequisites for such a highly specialized surgical department are adequate number of beds, consultant surgeons, properly trained doctor and nursing staffs, a well equipped modern operation theatre attached with a fully organized neonatal ICU, a modern pathological laboratory and radiological service with pediatric expertise. It also needs a modern documentation center for proper hospital records and a dependable hospital supply. Unfortunately some of them are still absent in this hospital and others are inadequate.

Adequate budget allocation, coordinated initiative and sincere effort by the senior hospital administrators are essential to overcome all these limitations. A regular evaluation of the overall performance, quality of services could be found by introducing medical/ surgical audit in all the sectors of health services in Bangladesh. This will improve the accountability and transparency in this sector to the peoplew.

\section{References}

1. H.B. Devlin, Founding Director of the Surgical Epidemiology and Audit Unit, Royal College of Surgeons of England

2. Seth Allcorn, Internal Auditing for hospital, 1979. Aspin system corporation, Germantown, Maryland, London.

3. Islam S J Disease Pattern in children. Bangladesh J Child Health Health 1991:Vol 15(3/ 4): 63-65

4. Peter G. Jones and Alan A. Woodward. Clinical Paediatric Surgery (Third Edition) 1989. Blackwell Scientific publication.

5. Philip L. Glick \& Scott C. Boulanger. Inguinal Hernias and Hydroceles.

6. Haq M N Rahman MD, Azad AK Haque M. Study on Hospital organization and administration in Bangladesh (Final Report), 1993. Ministry of Health \& Family Welfare. Govt. of peoples Republic of Bangladesh in Collaboration with WHO.

7. Matin Al Helal, Z. A Medical Audit Paper presented in $13^{\text {th }}$ national congress of Bangladesh Medical association, 1994.

8. Ashraf-Ul-Haque, S. M. Safiruddin Ahmed. An Audit of the Patients treated in Paediatric Sugical Unit of $\mathrm{DMCH}$. 